VOX PATRUM 20 (2000) t. 38-39

Ks. Stanisław LONGOSZ (Lublin)

\title{
ATANAZJAŃSKA TERMINOLOGIA TEOLOGII WCIELENIA
}

Zasadniczą treścią teologii św. Atanazego Aleksandryjskiego (296-373) jest, obok obrony bóstwa Syna Bożego przed arianizmem, nauka o Jego wcieleniu - przyjęciu przez Niego człowieczeństwa dla naszego zbawienia. To jemu zawdzięczamy pierwszy wczesnochrześcijański zachowany ${ }^{1}$ traktat $O$ wcieleniu Stowa ${ }^{2}$, napisany w młodości ok. 320 roku, jeszcze za diakonatu, przed swym biskupstwem i oficjalną batalią z arianizmem. To jemu również przypisuje się często powtarzaną, sławną sentencję: „Bóg stał się człowiekiem, by człowiek stał się bogiem”3, lub „Słowo nie tylko zstąpiło na człowieka, lecz stało się człowiekiem"4. Te i inne jeszcze lapidarniejsze wyrażenia i wypowiedzi, dotyczące przybrania przez Logos natury ludzkiej, uczyniły z Atanazego Aleksandryjskiego pierwszego większego teologa tajemnicy wcielenia, czemu poświęcono już niemałą literaturę objaśniającą nie tylko jego naukę o samym

${ }^{1}$ Wcześniej o wcieleniu specjalny traktat w trzech księgach miał napisać w II wieku Meliton z Sardes (Euseb. IV 26,2): O wcieleniu Chrystusa przeciw Marcjonowi, ale dzieło to zaginęło, por. SCh 123, Paris 1966, 226.

${ }^{2}$ Por. Oratio de incarnatione Verbi, PG 25, 96-197; R.W. Thompson: Athanasius, Contra gentes and De incarnatione, Oxford 1971 (tekst grecki + przekład angielski); ed. Ch. Kannengiesser: Athanase d'Alexandrie, Sur l'Incarnation du Verbe, SCh 199, Paris 1973, 1-256 (Introduction), 258-469 (nowy krytyczny tekst grecki + przekład francuski); w wersji syryjskiej: CSCO 257, 1-72 (tekst), CSCO 258, 1-54 (przekład); przekład polski: M. Wojciechowski: Atanazy z Aleksandrii, O Wcieleniu Słowa, PSP 61, Warszawa 1998, 1-20 (wstęp), 21-76 (przekład). Literatura: P.Th. Camelot, Introduction, w: Athanase d'Alexandrie, Contre les paiens et Sur l'Incarnation du Verbe, SCh 18, Paris 1946, 55-103 (Le traité de l'Incarnation du Verbe); Ch. Kannengiesser, Le texte court du De incarnatione athanasien, RSR 52 (1964) 589-596, 53 (1965) 77-111; tenże, Les différentes recensions du traité De Incarnatione Verbi de S. Athanase, „Studia Patristica” 7 (1966) 221229; A. Pettersen, A Reconsideration of the Date of the Contra gentes - De Incarnatione of Athanasius of Alexandria, „Studia Patristica” 17 (1982) 1030-1040; J. Quasten, Patrologia, II, Casale 1969, 27-29; M. Slusser, Contra gentes and De incarnatione of Athanasius of Alexandria, place and date of composition, JThS 37 (1986) 114-117.

${ }^{3}$ Parafraza De incarnatione 54, 3, SCh 199, 458, PSP 61, 73: „Ono bowiem się wcieliło, byśmy zostali ubóstwieni".

${ }^{4}$ Contra Arianos III 30, PG 26, 388A. 
wcieleniu ${ }^{5}$, ale również i jego skutki - zwłaszcza problem zbawienia i ubóstwienia człowieka ${ }^{6}$, a także zarzucaną mu negację duszy ludzkiej w Chrystu$\mathrm{sie}^{7}$. Ten Biskup Aleksandryjski ma jednak również niemałe zasługi w wypra-

5 Por. X. Le Bachelet, Athanase Saint 3, DThC I 2 2169-2171 (Incarnation); J.B. Berchem, L'Incarnation dans le plan divin d'après saint Athanase, „Echos d'Orient” 33 (1934) 316-330; L. Bouyer, L'Incarnation et l'Eglise-corps du Christ dans la théologie Athanase, Paris 1943; E. Contreras, Elementos de antropología teologíca cristiana en el „De Incarnatione Verbi” de Sant' Atanasio, „Stromata” 46 (1990) 361-395; D. McCoy-Jerry, Philosophical influences on the doctrine of the Incarnation in Athanasius and Cyril of Alexandria, „Encounter” 38 (1977) 362-371; G.D. Dragas, Enanthropesis or egeneto anthropos. A neglected aspect of Athanasius' Christology, „Studia Patristica” 16 (1985) 281-294); E.Galbiati, La dottrina di Sant'Atanasio sull'Incarnazione del Verbo, w: Simposio Cristiano, Milano 1976, 30-41; A. Gaudel, La théologie du Logos chez Saint Athanase, RSR 9 (1929) 524-539, 11 (1931) 1-26; A. Van Haarlem, Incarnatie en verlossing bij Athanasius, Wageningen 1961; Ch. Kannengiesser, Le Verbe de Dieu selon Athanase d'Alexandrie, Paris 1990; J.R. Meyer, Athanasius' Son of God Theology, „Recherches de Théologie et de Philosophie Mediévales" 66 (1999) 225-253; Th.V. Morris, The Metaphysics of God Incarnate, w: Trinity, Incarnation and Atonement, ed. R.J. Feenstra - C. Plantinga, Notre Dame 1989, 110-127; J. Roldanus, Le Christ et l'homme dans la théologie d'Athanase d'Alexandrie. Étude de la conjonction de sa conception de l'homme avec sa christologie, Leiden 1977; T.E. Pollard, Logos and Son in Origen, Arius and Athanasius, „Studia Patristica” 2 (1957) 282-287; K.E. Skurat, Die Heilbedeutung der Menschenwerdung Christi nach der Lehre des hl. Athanasius, „Stimmen der Orthodoxie” 8 (1975) 46-50; 9 (1975) 53-57; K.J. Thorjesen, The Teaching Function of the Logos: Athanasius, De incarnatione 20-32, w: Arianism. Historical and theological reassessments, ed. R. Gregg, Cambridge Mass. 1985, 213-221; G. Voisin, La doctrine christologique de S. Athanase, RHE 1 (1900) 226-248, spec. 230-236; E. Weigl, Untersuchungen zur Christologie des heiligen Athanasius, Paderborn 1914 .

${ }^{6}$ Por. J.B. Berchem, Le rôle du Verbe dans l'oeuvre de la creation et de la sanctification d'après saint Athanase, „Angelicum” 15 (1938) 201-232, 515-558; K. Bornhaeuser, Die Vergottungslehre des Atanasius und Johannes Damascenus, Gütersloh 1903; M. Lot-Borodine, La déification de l'homme, Paris 1970; J. Gross, La divinisation du chrétien d'après les Péres Grecs, Paris 1938; J. Lebon, S. Athanase a-t-il employé l'expression „ho kyriakos anthropos”, RHE 31 (1935) 307329; J. Pagór, Skutki wcielenia Jezusa Chrystusa według św. Atanazego Wielkiego, "Cerkiewny Wiestnik” 1999, nr 4, 3-7; E.C. Saliani, Restaurazione dell'imagine nella „Oratio de Incarnatione” di s. Atanasio di Alessandria, „Nicolaus” 2 (1974) 361-367; K. Scurat, La doctrine de Saint Athanase le Grand sur la divinisation, trad. J.V. Parasciv, „Mitropolia Olteniei. Craiova” 26 (1974) 938-944; C.R. Strange, Athanasius on Divinisation, ,Studia Patristica” 16 (1985) 342-346; H. Straeter, Die Erlösungslehre des hl. Athanasius, Freiburg 1894; G. Telepneff - J. Thorn, Transcendence and the notion of theosis in saint Athanasios, ,The Greek Orthodox Theological Review" 32 (1987) 271277; L. Vicario, Creazione e restaurazione dell uomo cc. 1-32 del „De Incarnatione” di S. Atanasio, „Nicolaus” (1981) 63-127.

7 Por. C. Constantinides, Edidasken ho Megas Athanasios hoti eichen anthropinen psychen ho Christos?, „Orthodoxia Istanbul” (1954) 286-293, 446-452, (1955) 92-98, (1956) 69-78; P. Galtier, S. Athanase et l'âme humaine du Christ, „Gregorianum” 36 (1955) 553-589; Ch. Kannengiesser, Logos et nous chez Athanase d'Alexandrie, ,Studia Patristica” 11 (1972) 199-202; J. Lebon, Une ancienne opinion sur la condition du corps du Christ dans la mort, RHE 23 (1927) 5-43; A. Louth, Athanasius' understanding of the humanity of Christ, ,Studia Patristica” 16 (1985) 309-318; tenże, The concept of the soul in Athanasius' Contra gentes - De incarnatione, ,Studia Patristica” 13 (1975) 227-231; I. Ortiz de Urbina, L'anima umana di Cristo secondo S. Atanasio, „Orientalia Christiana 
cowaniu właściwej terminologii teologii wcielenia. Przy jego objaśnianiu, gdy jeszcze nie było ustalonego w tym względzie słownictwa, używał on wielu i bardzo różnorodnych słów, albo przejmując już wcześniej używane lub tworząc nowe terminy, albo też nadając powszechnie używanym pospolitym wyrazom treść chrystologiczną. Na ten problem zwrócił uwagę przed 30 laty wydawca najnowszego krytycznego tekstu atanazjańskiego traktatu $O$ wcieleniu Stowa Ch. Kannengiesser, który we wstępie do niego ${ }^{8}$ obliczył w oparciu o Lexicon Athanasianum ${ }^{9}$, że ten Biskup przy objaśnianiu tej prawdy wiary użył w sumie aż 51 różnych czasowników i 18 rzeczowników. Na określenie samego aktu wcielenia, czyli przyjęcia, przez Słowo natury ludzkiej (ciała), użył w tym traktacie aż 18 różnych czasowników, 5 rzeczowników i kilka złożonych określeń ${ }^{10}$. Warto tu przypomnieć ich kilkanaście przykładów, by sobie uzmysłowić, jak rodziło się teologiczne słownictwo wcielenia, co starało się ogólnie przybliżyć już kilku autorów ${ }^{11}$.

\section{CZASOWNIKI}

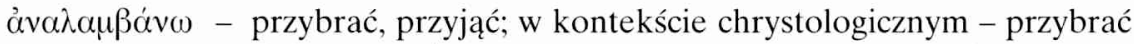
ciało - $\sigma \tilde{\omega} \mu \alpha)$. W tym bezpośrednim sformułowaniu występuje u Atanazego tylko raz w jego traktacie $O$ wcieleniu ${ }^{12}$, w nieco zaś zmienionej strukturze (ale z $\sigma \tilde{\omega} \mu \alpha)$ jeszcze dwa razy w innych jego pismach ${ }^{13}$. Pod wpływem Flp 2,7 spotyka-

Periodica” 20 (1954) 27-43; A. Pettersen, Athanasius and the human body, Bristol 1990; M. Richard, Saint Athanase et la psychologie du Christ selon les Ariens, „Mélanges des Sciences Religieuses” 4 (1947) 5-54.

${ }^{8}$ Por. Introduction, w: Athanase d'Alexandrie, Sur l'Incarnation du Verbe, SCh 199, Paris 1973, 85-137.

${ }^{9}$ Por. G. Müller, Lexicon Athanasianum, Berlin 1952.

${ }^{10}$ Por. Introduction s. 94.

${ }^{11}$ Por. m.in. M. Elze, Inkarnation I, w: Historisches Wörterbuch der Philosophie, IV, Basel 1976, 368-369; A. Michel, Incarnation I 1, DThC VIIb, Paris 1923, 1446-1450 (Etymologie); J.L. Oreja, Terminología patristica de la encarnacion, „Helmantica” 2 (1951) 129-160; V. Loi, La latinità cristiana nel De Trinitate di Novaziano, „Rivista di cultura classica e medievale” 13 (1971) 136-177 (incarnatus).

${ }^{12}$ Por. De incarnatione 45, I, SCh 199, 430, PSP 61, 65: „W następstwie tego Boże Słowo

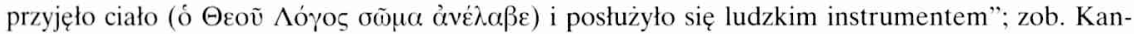
nengiesser, Introduction s. 101-102; Müller, Lexicon Athanasianum 77.

${ }_{13}$ Por. Contra Arianos II 44, PG 26, 241B: „Pewnym zaś jest, że nasze ciało jest domem

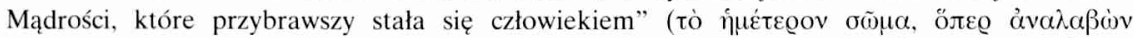

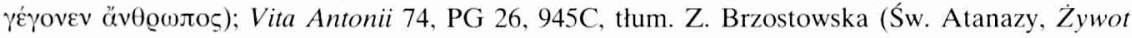
świętego Antoniego, Warszawa 1987) s. 100: „,co jest lepsze: twierdzić, że Słowo Boże jest niezmien-

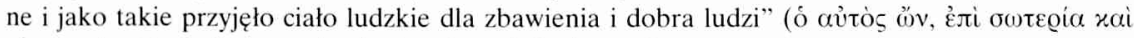

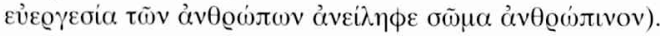




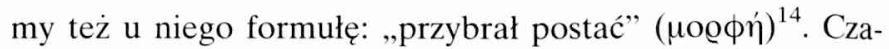
sownik ten w kontekście chrystologicznym spotykamy również w literaturze pseudoatanazjańskiej ${ }^{15}$, a zwłaszcza u arian w formule: ,przybrać człowieka”,16.

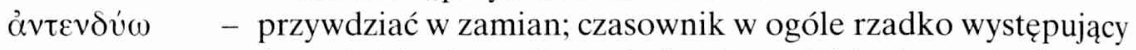
(wcześniej tylko u Plutarcha), w kontekście chrystologicznym - przywdziać ciało; w pismach Atanazego występuje tylko raz w traktacie $O$ wcieleniu $^{17}$, nie poświadczają go ani późniejsza literatura pseudoatanazjańska, ani inna patrystyczna, i stanowi atanazjański hapax legomenon.

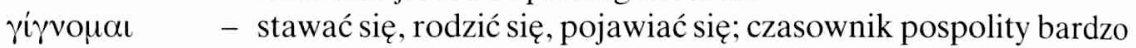
często używany, w kontekście chrystologicznym pod wpływem J 1,14 - stawać się ciałem lub człowiekiem, Słowo (Bóg) stało się ciałem lub człowiekiem. W traktacie $O$ wcieleniu pojawia

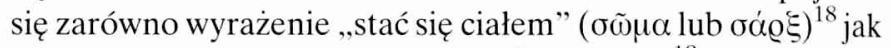

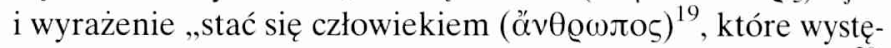
puje bardzo często w późniejszych pismach atanazjańskich ${ }^{20}$.

${ }^{14}$ Por. Contra Arianos I 38, PG 26, 89: „kiedy stał się człowiekiem i przybrał postać sługi” (ötع

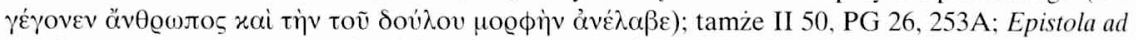

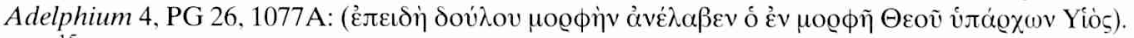

15 Por. Contra Apollinarium I 15, PG 26, 112lA: „Daremnie zatem arianie mędrkują twier-

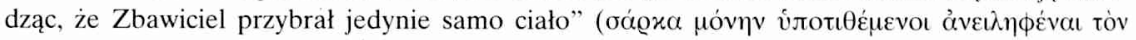
$\Sigma \omega \tau \tilde{\eta} \varrho \alpha)$.

16 Por. m.in. Contra Arianos IV 15, PG 26, 4-488C: „Jedni bowiem twierdzą, że człowiek, którego Zbawiciel przybrał, jest Synem" ( PG 26, 744A: ,Jak zaś uczą wszystkie Pisma, a zwłaszcza Apostoł nauczyciel narodów, ze Chrystus

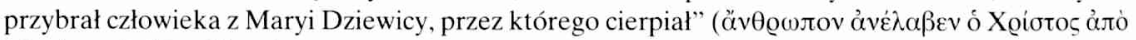

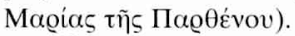

17 Por. De incarnatione 44, 5, SCh 199, 426, PSP 61, 64: ,Jeśli jednak spoiła się śmierć z ciałem i jako zjednoczona z nim zapanowała też nad nim, konieczne było, by i życie z ciałem się spoiło,

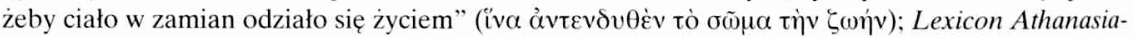
num 98; Kannengiesser, Introduction s. 94; H.G. Liddell - R. Scott, A Greek-English Lexicon, Oxford 1966, s. 151; G.W.H. Lampe, A Patristic Greek Lexicon, Oxford 1978, s. 151.

18 Por. np. De incarnatione 4, 3, SCh 199, 276, PSP 61, 25: „,dla naszego zbawienia pokochal

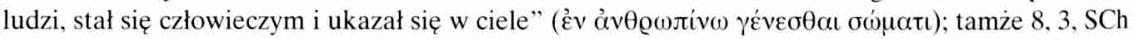

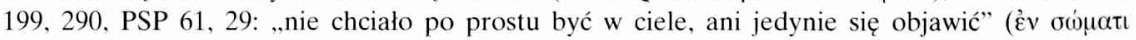

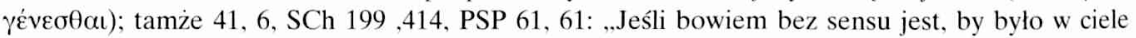

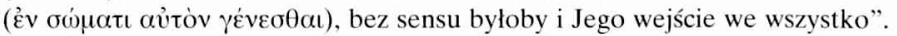

${ }^{19}$ Por. De incarnatione 44, 2, SCh 199, 424, PSP 61, 64: „Dlatego stał się czlowiekiem ( $\gamma \varepsilon ́ \gamma o v \varepsilon$

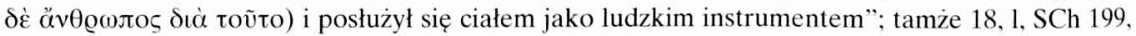

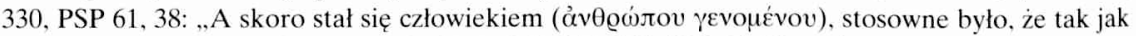
o człowieku o Nim mówiono”; tamże 18, 3, SCh 199, 330, PSP 61, 38: „tak gdy stał się człowiekiem

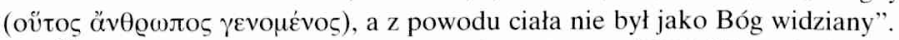

${ }^{20}$ G. Müller w swoim Lexicon Athanasianum (227-245) znalazł aż 105 zastosowań tego wyrażenia w samych Mowach przeciw arianom; zob. Kannengiesser, Introduction s. 98. 
Jedno i drugie wyrażenie figuruje także często we wcześniejszej i późniejszej literaturze patrystycznej ${ }^{21}$.

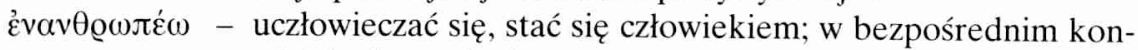
tekście chrystologicznym - Słowo (Bóg) stało się człowiekiem dla naszego zbawienia. Czasownik należący do klasycznej terminologii teologii wcielenia, występował już wcześniej u Justyna, w literaturze gnostyckiej, u Orygenesa, Hipolita, Piotra Aleksandryjskiego, Euzebiusza, Cyryla Jerozolimskiego, Metodego z Olimpu i wielu innych ${ }^{22}$. Św. Atanazy, ku naszemu zdziwieniu, mimo tak długiej wcześniejszej tradycji użył tego czasownika tylko 2 razy w swoim traktacie $O$ wcieleniu $^{23}$, preferując $w$ innych swoich pismach wyrażenie

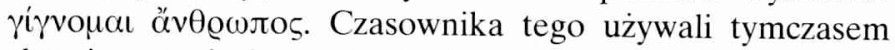
chętnie antynicejczycy i arianie nawet w swoich symbolach wiary, których Atanazy przytacza aż 7 w swoim De synodis ${ }^{24}$, a także sam Symbol Nicejski, którego tekst przesyła w liście do cesarza Jowiana ${ }^{25}$. Występuje on również często w literaturze pseudoatanazjańskiej ${ }^{26}$, oraz $\mathrm{u}$ innych współczesnych (Apolinary, Grzegorz z Nazjanzu, Jan Chryzostom) i późniejszych Ojców Kościoła (Epifaniusz, Teodoret z Cyru, Proklos z Konstantynopola, Maksym Wyznawca ${ }^{27}$ ).

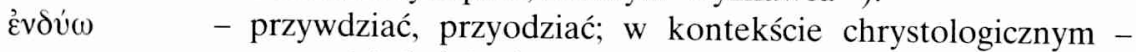
przywdziać ciało (człowieka) przez Słowo (Boga); Atanazy używa tego czasownika w swoich pismach dość często (w De decretis Nicaenae synodi, De sententia Dionysii, Contra Arianos I-III, Epistola ad Adelphium $)^{28}$, a w jednym z miejsc

21 Por. Lampe s. 35.

22 Por. Lampe s. 462.

23 Por. De incarnatione 10,3, SCh 199, 300, PSP 61, 31: „Następnie naznaczono przyczynę, dla

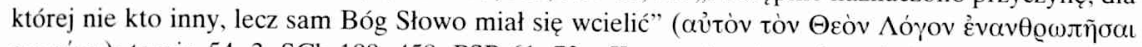

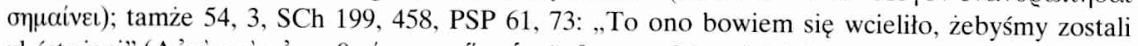

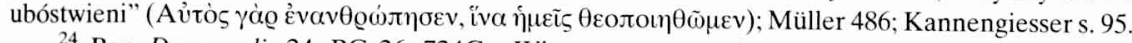

${ }^{24}$ Por. De synodis 24, PG 26, 724C: „Wierzymy w... zrodzonego z Dziewicy według Pism,

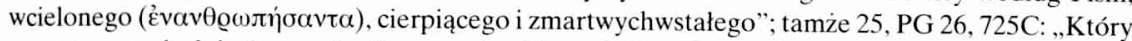

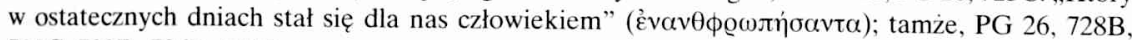
729C, 732B, 736B, 745B.

${ }^{25}$ Por. Epistola ad Jovianum 3, PG 26, 817B: „Który dla nas ludzi i dla naszego zbawienia

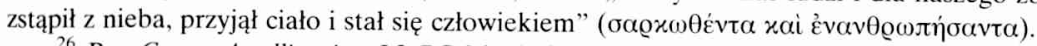

${ }^{26}$ Por. Contra Apollinarium I 2, PG 26, 1096A: „następnie zstąpił dla naszego zbawienia, przyjął

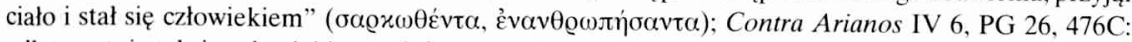

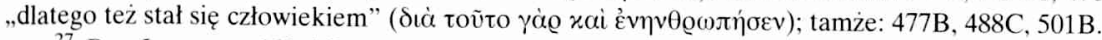

27 Por. Lampe s. 462-463.

${ }^{28}$ Por. De decretis Nicaenae synodi 10, PG 25, 440D; De sententia Dionysii 19, PG 25, 508D: „aby pokazać, że nie Ojciec, lecz Syn przywdział zrodzone, stworzone i uczynione ciało” ( $\dot{\alpha} \lambda \lambda$ ’ $\delta$ 
traktatu $O$ wcieleniu aż 4 razy $^{29}$. Czyni to przeważnie w ao-

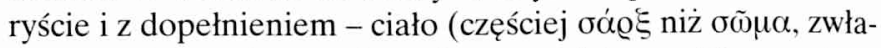
szcza w Mowach przeciw arianom, gdzie na 26 razy jego użycia, 19 razy występuje $\sigma \alpha ́ \varrho \xi$, a tylko 6 razy $\sigma \tilde{\omega} \mu \alpha)^{30}$. W używaniu tego czasownika w kontekście chrystologicznym nasz Biskup nie był oryginalny, bo posługiwano się nim już wcześniej (ebionici, Klemens Aleksandryjski, Hipolit) i później (Epifaniusz, Teodoret i inni) ${ }^{31}$.

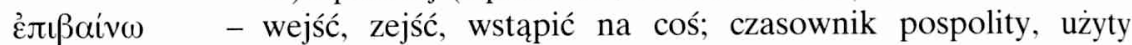
w kontekście chrystologicznym oznacza - wejść, wstąpić w ciało (człowieka) przez Słowo (Boga). Św. Atanazy użył tego czasownika w kontekście chrystologicznym zaledwie 4 razy $^{32}$.

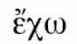

- mieć, posiadać; w kontekście chrystologicznym - Słowo (Bóg) ma ludzkie ciało, by przez nie móc umrzeć i odkupić człowieka. Biskup Aleksandryjski użył tego czasownika posiłkowego 7 razy w tym stosunkowo rzadko stosowanym kontekście chrystologicznym ${ }^{33}$.

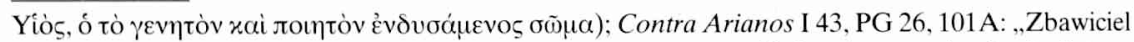

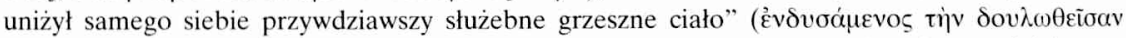

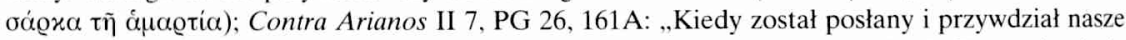

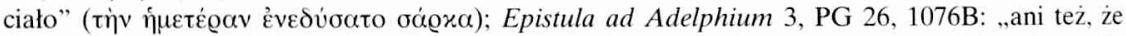

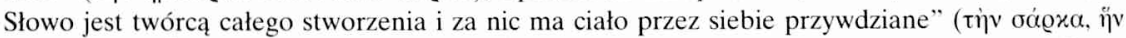

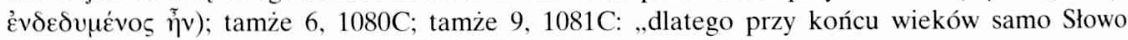

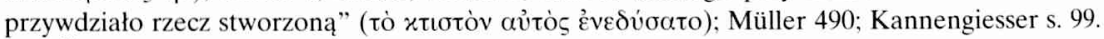

${ }^{29}$ Por. De incarnatione 44, 6, SCh 199, 4-28, PSP 61, 64: „Dlatego słusznie Zbawca odział się

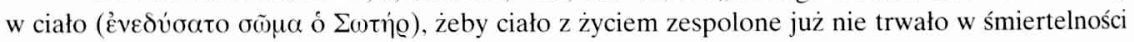

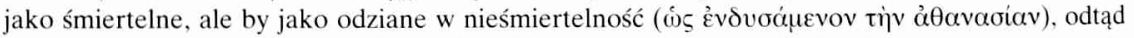
zmartwychwstawszy trwało nieśmiertelne. Raz bowiem odziane ( $\varepsilon v \delta v \sigma a ́ \mu \varepsilon v o v)$ w rozkład nie

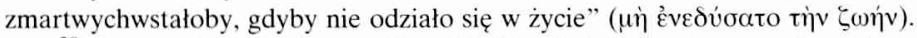

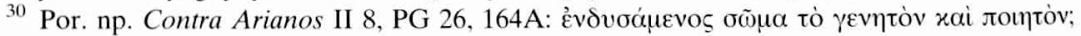

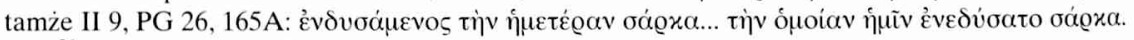

31 Por. Lampe s. 469.

32 Por. De incarnatione 43, 4, SCh 199, 422, PSP 61, 63: „przyjmuje sobie za instrument część

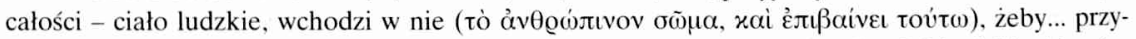
najmniej w owej części go poznali”; tamże 31, 4, SCh 199, 378, PSP 61, 50: „Jaki miał być koniec

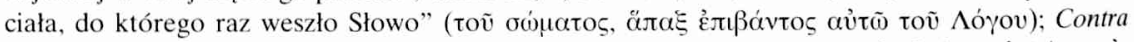

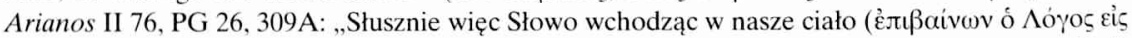

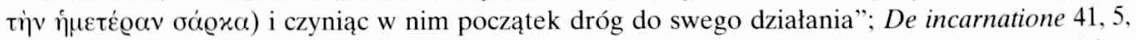
SCh 199, 414, PSP 61, 61: „Jeśli bowiem Boże Słowo jest w świecie, który jest ciałem... cóź jest

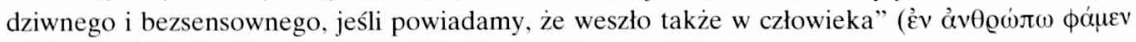

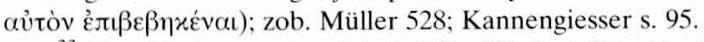

33 Por. De incarnatione 21, 7, SCh 199, 344, PSP 61, 41: „Dlaczego zatem nie powstrzymał

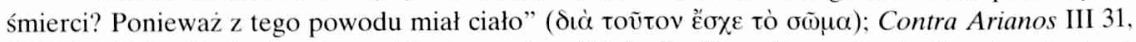

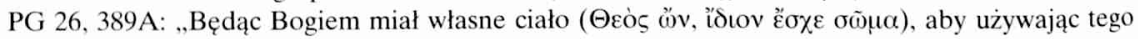




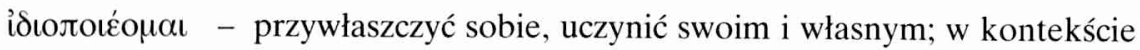
chrystologicznym - Słowo uczyniło własnym ludzkie ciało. Atanazy jako pierwszy użył tego czasownika w kontekście chrystologicznym 5 razy $^{34}$, potem w analogicznym znaczeniu występuje on również w literaturze pseudoatanazjańskiej ${ }^{35}$ i u kilku późniejszych Ojców Kościoła ${ }^{36}$.

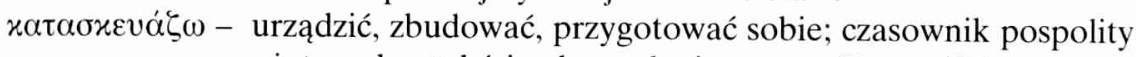
użyty w kontekście chrystologicznym - Słowo (Bóg, Zbawiciel) przygotowało sobie w Maryi Dziewicy ciało (mieszkanie, świątynię). U św. Atanazego w tym kontekście występuje 6 razy oznaczając zarówno sam akt wcielenia ${ }^{37}$ jak i jego skutek - ubóstwienie człowieka ${ }^{38}$.

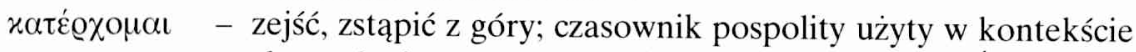
chrystologicznym - Słowo (Bóg) zstąpiło z nieba. Św. Atanazy użył tego czasownika w tym kontekście 5 razy ${ }^{39}$.

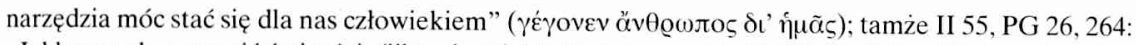

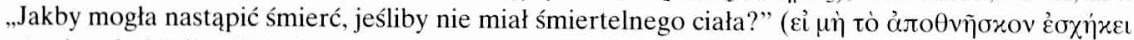
$\sigma \tilde{\omega} \mu \alpha)$; zob. Müller 596; Kannengiesser s. 99-100.

${ }^{34}$ Por. De incarnatione 8, 3, SCh 199, 292, PSP 61, 29: „W Dziewicy przygotowało sobie ciało na przybytek i własnym je uczyniło jako instrument" ( ọ̋ $\gamma$ ovov); tamże 31, 4, SCh 199, 378, PSP 61, 50: „Jeśli całkiem przyjął dla siebie ciało i słusznym

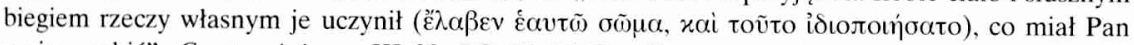
z nim zrobićc; Contra Arianos III 33, PG 26, 393B: „Skoro teraz Słowo stało się człowiekiem

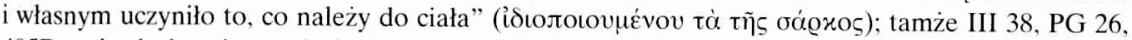
405B: ,aby łaska nie mogła być utracona i ludzie stale ją posiadali, On przywłaszczył sobie jej

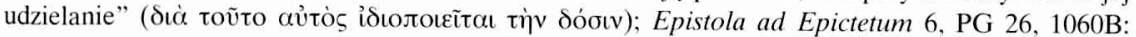

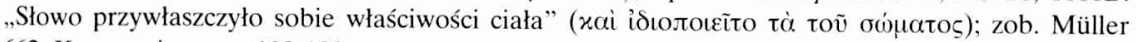
662; Kannengiesser s. 102-103.

${ }^{35}$ Por. Ps-Athanasius, Contra Arianos IV 22, PG 26, 500C; Contra Apollinarium I 12, PG 26 , 1113A: „postać sługi, którą samo Słowo poprzez naturalne urodzenie swoją uczyniło” (av̉iò ó

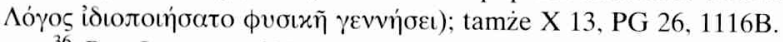

36 Por. Lampe s. 664.

37 De incarnatione 8, 3, SCh 199, 292, PSP 61, 29: „W Dziewicy przygotował sobie ciało na przybytek" ( 61, 50: „, [ciało] nie mogło nie umrzeć, skoro było śmiertelne i za wszystkich na śmierć ofiarowane;

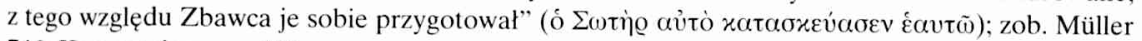
746; Kannengiesser s. 100.

38 Por. Contra Arianos I 51, PG 26, 120A: „Pan zatem, który zawsze i z natury jest niezmienny, który kocha sprawiedliwość, a nie toleruje niegodziwości, jest namaszczony i posłany, aby przybrawszy zmienne ciało trwał w nim i potępił w nim grzech oraz przygotował je wolne do wypełnie-

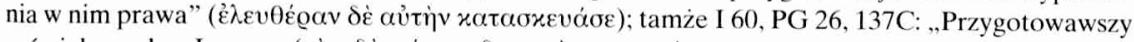

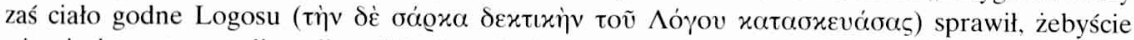
więcej nie postępowali według ciała lecz ducha"; tamże III 56, PG 26, 441A; tamże III 58, PG

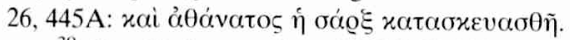

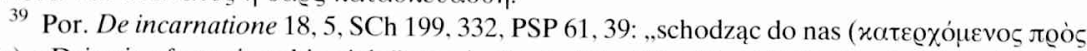

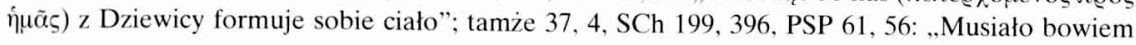


oixź $\omega$

$\pi \lambda \alpha \dot{\tau} \tau \omega$

- zamieszkać, ulokować się, przebywać; czasownik pospolity, ale nierzadko stosowany w kontekście chrystologicznym, zwłaszcza w teologii antiocheńskiej, na oznaczenie zamieszkania Boga (Logosu) w ludzkim ciele ${ }^{40}$. Atanazy jako przedstawiciel teologii aleksandryjskiej użył tego czasownika w tym kontekście chrystologicznym tylko jeden raz $^{41}$, na oznaczenie samego aktu wcielenia, nie określając jednak tutaj zamieszkania Słowa w człowieku w sensie teologii antiocheńskiej. Biskup nasz użył tego czasownika w sensie teologicznym jeszcze trzy razy: na oznaczenie zamieszkania Logosu w ludziach przez łaskę uświęcającą ${ }^{42}$, i dwa razy na oznaczenie obecności Ducha Świętego w chrześcijanach ${ }^{43}$, w nawiązaniu do myśli św. Pawła (Ef 3,16-17).

- utworzyć, uformować, ukształtować; czasownik pospolity, spotykany kilkakrotnie w Septuagincie $(\operatorname{Rdz} 2,7 ; \mathrm{Wj} 32,4$; Iz 49, 5; Zach 12, 1), w kontekście chrystologicznym oznacza - Syn Boży (Słowo) uformował sobie ciało w(z) Maryi Dziewicy. Św. Atanazy użył tego czasownika w tym kontekście chrystologicznym kilka razy ${ }^{44}$.

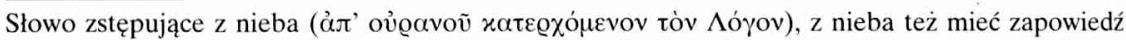
znaku”; tamże 37, 6, SCh 199, 398, PSP 61, 56: „Dopiero gdy Pan wszystkiego unosząc się jak na

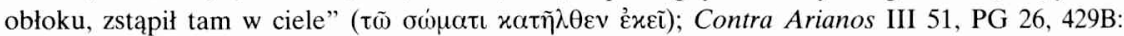

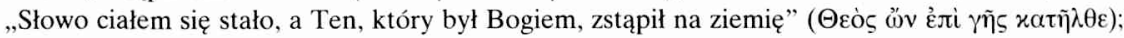
Epistula ad Maximum 4, PG 26, 1089B; zob. Kannengiesser s. 103.

40 Por. Lampe s. 939.

41 Por. De incarnatione 9, 4, SCh 199, 296, PSP 61, 30: „Gdy przybył do naszej krainy

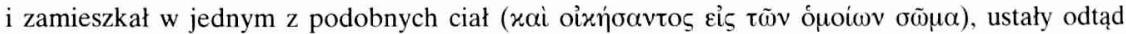
wszelkie zasadzki przeciw ludziom ze strony wrogów”; zob. Müller 971; Kannengieser s. 95-96.

${ }^{42}$ Por. Contra Arianos II 61, PG 26, 276C: „Bóg Stwórca ludzi przez swoje Słowo, które w nich

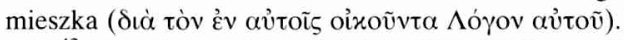

43 Por. Contra Arianos II 74, PG 26, 304B: „staliśmy się świątynią mieszkającego w nas Ducha

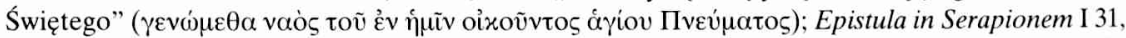
PG 26, 601B, ŹMT 2, 105: „wraz z Nimi przychodzi też Duch Święty, który zamieszkuje w nas (દ̉v

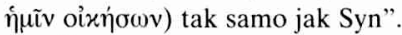

44 Por. De incarnatione 18, 5, SCh 199, 332, PSP 61, 39: „Dlatego też na początku schodząc do

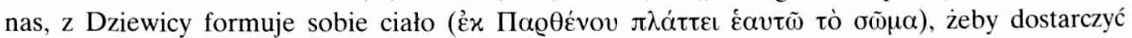

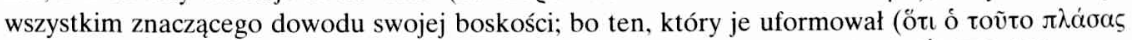

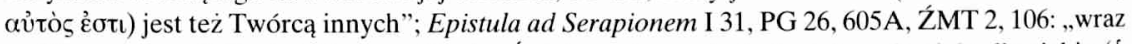
ze Słowem zstąpił Duch i Słowo w Duchu Świętym utworzyło i ukształtowało ciało dla siebie (ó $\Lambda$ mu przez siebie byty stworzone"; Contra Arianos II 11, PG 26, 169A; tamże II, 53, PG 26, 260A; Epistula ad Adelphium 7, PG 26, 1081B: „najświętsze i prawdziwie godne czci ciało Pana, które przez Gabriela archanioła zostało zapowiedziane, przez Ducha Świętego zostało uformowane"

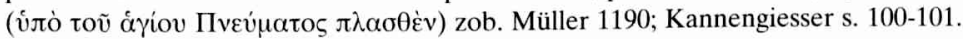




\section{RZECZOWNIKI}

Obok wyżej wymienionych czasowników, stosowanych w kontekście chrystologicznym na określenie tajemnicy wcielenia, Atanazy użył również, jak zauważył Ch. Kannengiesser, 5 konkretnych rzeczowników na oznaczenie -

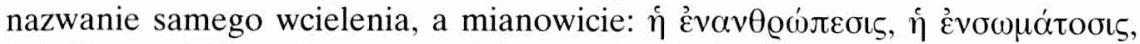

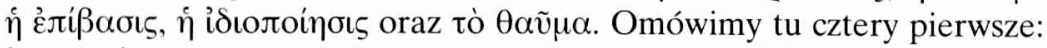

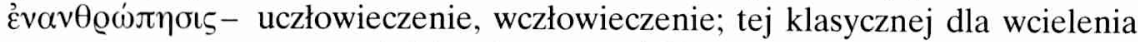
nazwy użył św. Atanazy aż 20 razy, w tym 10 razy w samym traktacie $O$ wcieleniu (również w jego tytule) oraz 10 razy w pozostałych swoich pismach. Przez użycie tej właśnie nazwy chciał zapewne nasz Biskup podkreślić, że Logos przyjął całego człowieka, pełną ludzką naturę. W traktacie $O$ wcieleniu termin ten występuje w samodzielnie lub w trzech następujących konstrukcjach:

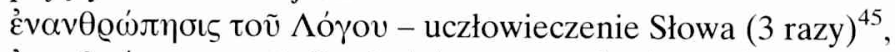

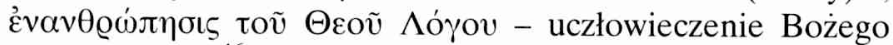
Słowa (2 razy) ${ }^{46}$,

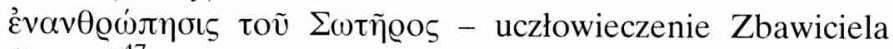
$(3 \text { razy })^{47}$,

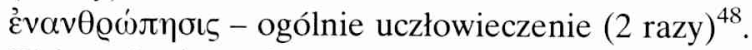

$\mathrm{W}$ innych pismach atanazjańskich termin ten występuje już sam, bez powyższych stałych konstrukcji, oznaczając ogólnie

45 Por. De incarnatione 1, 1, SCh 199, 260, PSP 61, 21: „Opowiedzmy o wcieleniu Słowa” (лع@i

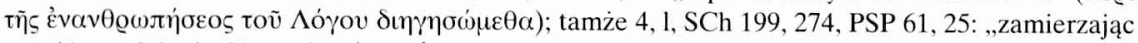

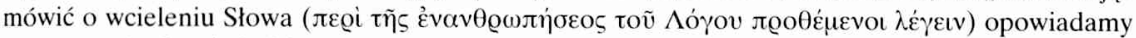
teraz o pochodzeniu ludzi”; tamże 54, 2, SCh 199, 453, PSP 61, 73: ,przez wcielenie Słowa poznana została powszechna opatrzność" (

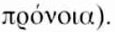

${ }^{46}$ Por. De incarnatione 10, 5, SCh 199, 300, PSP 61, 31: „Skoro bowiem z winy ludzi śmierć

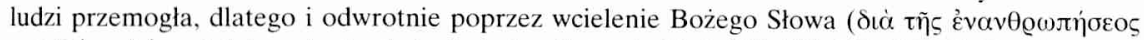

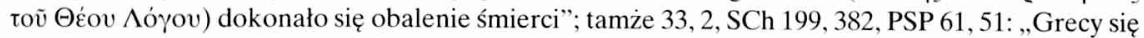
śmieją wyszydzając niestosowność krzyża i wcielenia Bożego Słowa" (

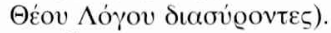

47 Por. De incarnatione 10, 6, SCh 199, 302, PSP 61, 32: „Taka jest oto pierwsza przyczyna

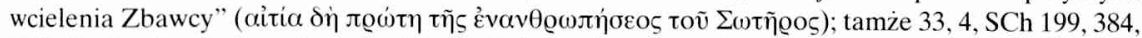
PSP 61, 52: „Mojżesz, który istotnie był wielki i uchodzi u nich za wiarygodnego, uważa za wielką

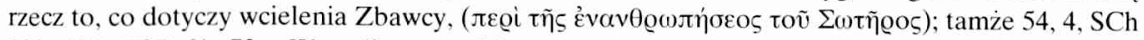
199, 458, PSP 61, 73: „W ogóle wspaniałe czyny Zbawcy dokonane przez Jego wcielenie ( $\tau \dot{\alpha}$

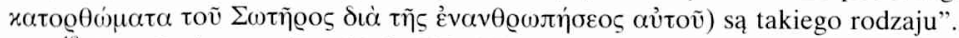

48 Por. De incarnatione 16, 3, SCh 199, 322, PSP 61, 37: „Słowo bowiem wszędzie się rozsze-

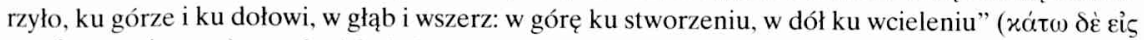

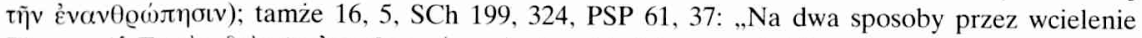

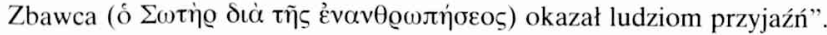


samo wcielenie, a mianowicie w De sententia Dionysii $(1 \mathrm{raz})^{49}$, w Contra Arianos I-III (6 razy $)^{50}$, w Epistola ad episcopos Aegypti et Libyae $(1 \mathrm{raz})^{51}$, Tomus ad Antiochenos $(1 \mathrm{raz})^{52}$, gdzie wyraz ten, podobnie jak w Symbolu Nicejskim $^{53}$ wzmocniony jest jeszcze terminem słrkwsij i w Epistola ad Adelphium (1 raz) ${ }^{54}$. W używaniu tego terminu przy omawianiu tajemnicy wcielenia św. Atanazy nie był jednak pierwszy ani oryginalny, bo przed nim na oznaczenie przyjęcia natury ludzkiej przez Słowo stosował go w połowie III wieku Hipolit Rzymski ${ }^{55}$ i Orygenes ${ }^{56}$, który posługiwał się

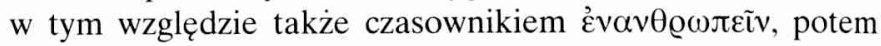

${ }^{49}$ Por. De sententia Dionysii 9, PG 25, 493A: „Te zaś słowa zostały powiedziane o Jego

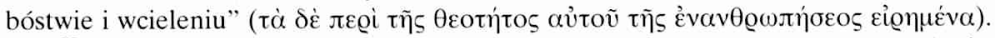

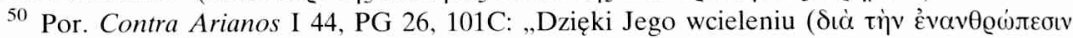

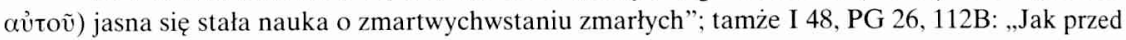

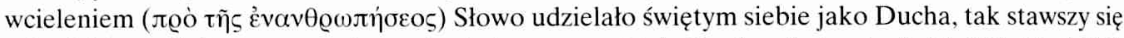

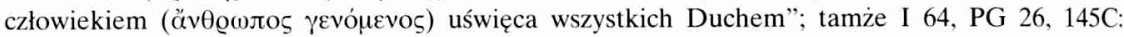

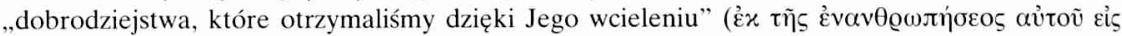

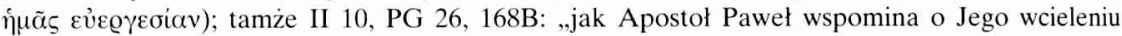

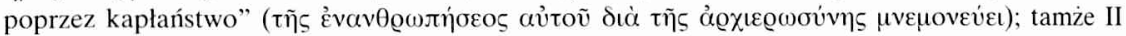

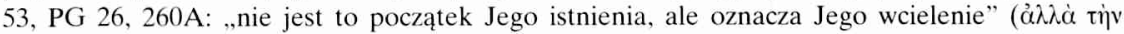

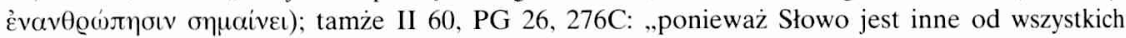

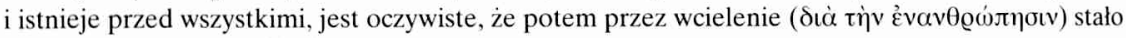
się początkiem wszelkich dróg”.

${ }^{51}$ Por. Epistola ad episcopos Aegypti et Libyae 17, PG 25, 577C: „Owe bowiem herezje błądzą

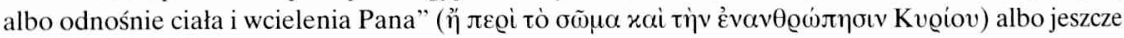
inne kłamstwa wygłaszają".

52 Por. Tomus ad Antiochenos 7, PG 26, 805A: „twierdzą, że to samo myślą o wcieleniu

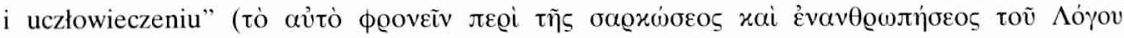

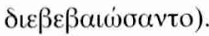

${ }^{53}$ Por. Symbolum Nicaenum, w: A. Hahn, Bibliothek der Symbole der alten Kirche, Hilde-

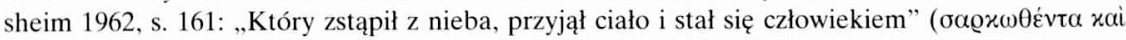
ह่v $\alpha v \theta 0 \omega \pi \eta \dot{\sigma} \sigma \alpha \tau \alpha)$.

54 Por. Epistola ad Adelphium 5, PG 26, 1077C: „Ci bowiem, którzy nie chcą wielbić Słowa,

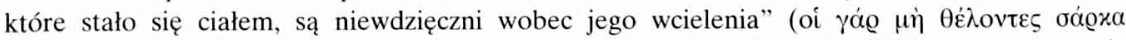

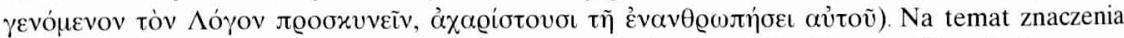

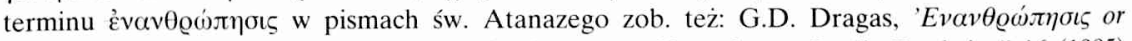

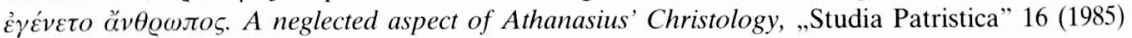
281-294, spec. 283-284; Müller 487; Kannengiesser s. 107-109.

55 Por. In Danielem IV 39, 4, SCh 14, 205.

56 Por. np. In Joannem VI 35, PG 14, 260A, thum. S. Kalinkowski, PSP 28, 194: ,wcielenie, to

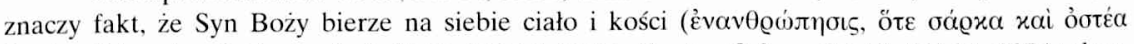

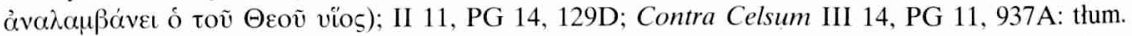
S. Kalinkowski (Orygenes, Przeciw Celsusowi, Warszawa 1986) s. 148: ,ze Jezus jest Synem Bożym

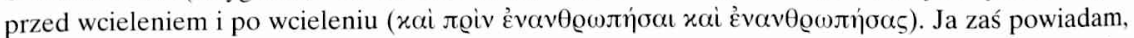
że tę naukę, w najwyższym stopniu godną Boga także po wcieleniu Jezusa ( $x \alpha i$ $\mu \varepsilon \tau \dot{\alpha}$ tìn

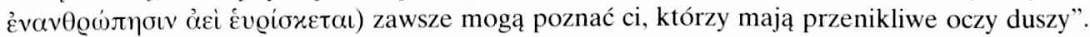


Metody z Olimpu ${ }^{57}$, Euzebiusz z Cezarei ${ }^{58}$, Cyryl Jerozolimski $^{59}$, ze współczesnych mu Paulin z Antiochii ${ }^{60}$, filoariańscy biskupi w swojej homouzjańskiej formule wiary (r. 345$346)^{61}$, autorzy pseudoatanazjańskich pism Contra Arianos IV $^{62}$ i Contra Apollinarium I-II ${ }^{63}$, gdzie nazwa ta wzmocnio-

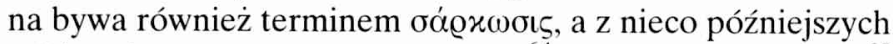
- Ojcowie Kapadoccy: Bazyli Wielki ${ }^{64}$, Grzegorz z Nazjanzu ${ }^{65}$ i Grzegorz z Nyssy ${ }^{66}$. Wynika z tego, że w czasach Atanazego

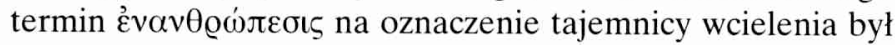
już powszechnie stosowany, do czego on sam mógł się rów-

57 Por. Symposium III 8, PG 18, 730, PSP 24, 47: „Duch prawdy może być nazwany żebrem,

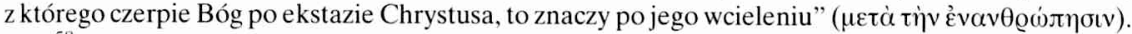

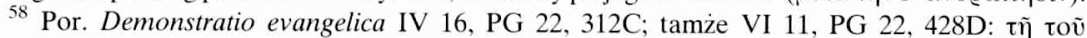

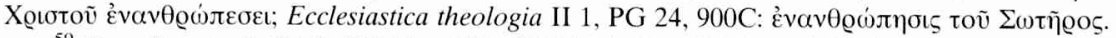

${ }^{59}$ Por. Catechesis IV 9, PG 33, 468A, BOK 14, 64: „Gdyby wcielenie było tylko pozorne,

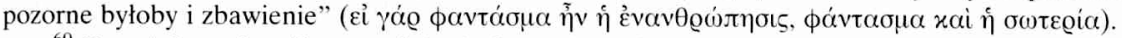

${ }^{60}$ Por. Athanasius, Tomus ad Antiochenos 11, PG 26, 809A: „O wcieleniu zaś Słowa Ojca,

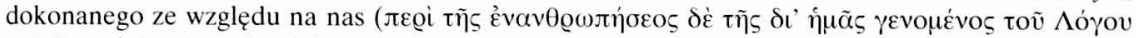

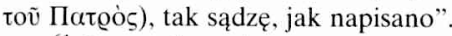

${ }^{61}$ Por. Athanasius, De synodis 7, PG 26, 732C: „My bowiem wiemy, że Ojciec, Który go posłał, pozostał we własnym stanie niezmiennego bóstwa, Chrystus zaś, który został posłany, wypełnił ekonomię wcielenia" (

${ }^{62}$ Por. Contra Arianos IV 4, PG 26, 488; tamże IV 23, PG 26, 501C: „Jeśli bowiem Słowo

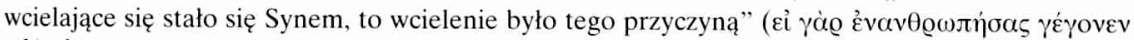

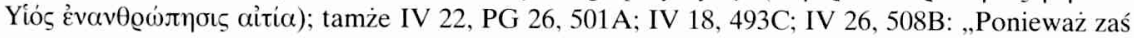

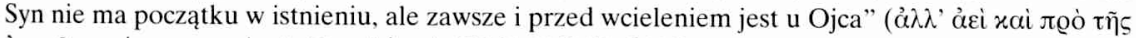

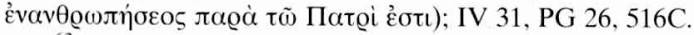

${ }^{63}$ Por. Contra Apollinarium I 21, PG 26, 1129C: „tak również manichejczyk, negujący wcie-

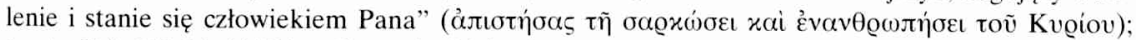
tamże II 2, PG 26, 1136A: „Czy twierdzicie, że to samo Słowo Boże niecierpiętliwe i niecielesne

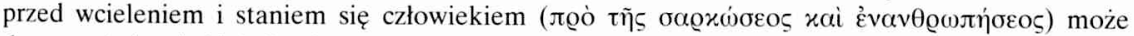
doznawać cierpień i śmierci”; tamże II 19, PG 26, 1165A: „Głupcami więc są ci, którzy albo Jego

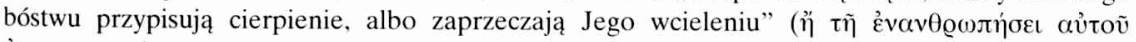

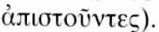

${ }^{64}$ Por. De Spiritu Sancto 57, PG 32,173B: „A w innym miejscu mówiąc o tajemnicy wcielenia”

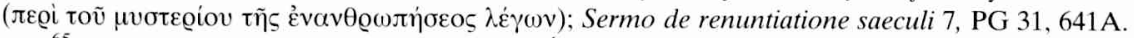

65 Por. Oratio 30, 14, PG 36, 121C, thum. (Św. Grzegorz z Nazjanzu, Mowy, Warszawa 1967) s. 338: „Posłuje bowiem jeszcze i teraz jako człowiek w sprawie mego zbawienia, ponieważ pozostaje z tym ciałem, które przybrał, dopóki mnie nie uczyni Bogiem siłą swego człowieczeństwa"

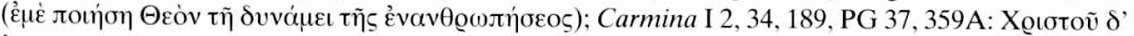

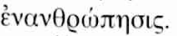

${ }^{66}$ Por. Oratio catechetica 26, PG 45, 690, tłum. T. Sinko (Św. Grzegorz z Nyssy, Wybór pism, Warszawa 1963) s. 106: „Takie i tym podobne dobrodziejstwa daje wielkie misterium boskiego

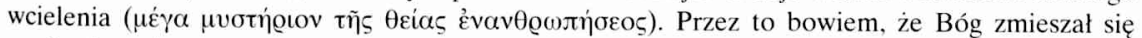
z człowieczeństwem, stawszy się człowiekiem we wszystkich właściwościach natury”; Epistola 2 , PG 46, 1113B, tłum. Sinko, tamże, s. 228: „O tym, że stał się człowiekiem przez dziewicę ( tìv dı่̀

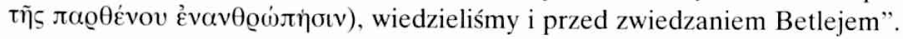


nież w niemałym stopniu przyczynić, znajdując się niewątpliwie pod wpływem teologii aleksandryjskiej, głównie Orygenesa.

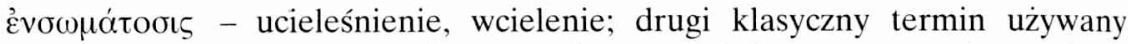
w teologii (choć o wiele rzadziej) na oznaczenie przyjęcia człowieczeństwa przez Słowo; Św. Atanazy użył go jednak tylko jeden raz w traktacie $O$ wcieleniu $^{67}$, i jest to u niego, jak się wyraża Ch. Kannengiesser idący za G. Müllerem, "absolutny hapax legomenon"68, choć gdzie indziej używa

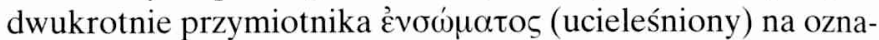
czenie cielesnego przyjścia Zbawiciela ${ }^{69}$. Również w użyciu tego rzeczownika nasz Biskup nie był pierwszym ani zupełnie oryginalnym, bo przed nim posługiwał się nim już Orygenes $^{70}$, a ze współczesnych mu - Bazyli Wielki ${ }^{71}$, a potem kilku innych Ojców Kościoła ${ }^{72}$.

Również pozostałych dwóch rzeczowników, które mają wprawdzie znaczenie ogólne i wieloznaczne, używał św. Atanazy kilka razy w kontekście chrystologicznym, a mianowicie:

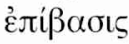

- zejście, zstąpienie na coś, wejście w coś; Atanazy użył tego rzeczownika w ścisłym kontekście chrystologicznym tylko 2 razy $^{73}$, a więc nieco rzadziej niż wspominanego wyżej czasow-

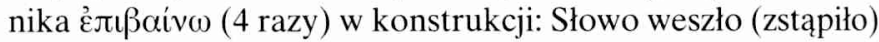

${ }^{67}$ Por. De incarnatione 4, 3, SCh 199, 276, PSP 61, 25: „My staliśmy się bowiem przyczyną

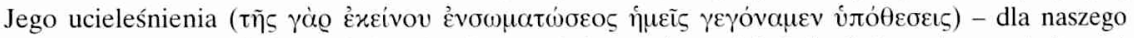
zbawienia pokochał ludzi, stał się człowieczym i ukazał się w ciele" ( $\phi \alpha v \tilde{\eta} \sigma \theta \mathrm{l})$.

${ }^{68}$ Por. Introduction s. 109: ,un hapax absolu”; G. Müller, Lexicon Athanasianum 495.

${ }^{69}$ Por. Contra Arianos I 53, PG 26, 124A: „Slowa zatem o nim zapisane, o cielesnym przyjściu

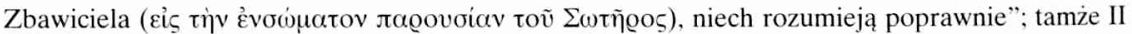
66, PG 26,285C: „Jasne niech będzie, że słowa o Nim: «Pan stworzył mnie początkiem dróg

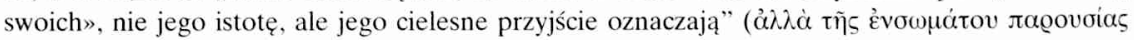
àvтоข̃).

${ }^{70}$ Por. In Joannem VI 5, 28, PG 14, 208B, PSP 28, 162: „Zdanie: «Wielu proroków i sprawiedliwych pragnęło zobaczyć to, co wy widzicie, a nie widzieli» (Mt 13, 17) może mieć podobny

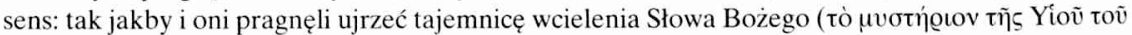

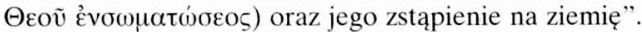

${ }^{71}$ Por. Hom. in Ps. 29, 1, PG 29 ,305C: ,Według duchowego rozumienia tytuł (psalmu)

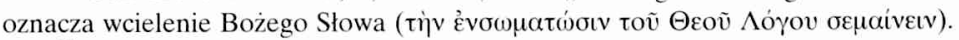

72 Por. Lampe s. 482.

73 Por. De incarnatione 20, 4, SCh 199, 338, PSP 61, 40: „Dzięki wejściu w nie [ciało] Słowa (

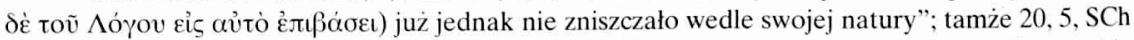
199, 340, PSP 61, 40-41: „przyjęło dla siebie ciało mogące umrzeć, aby jako własne ofiarować je

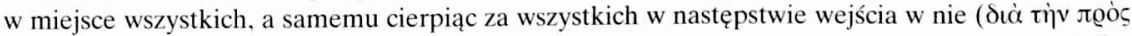

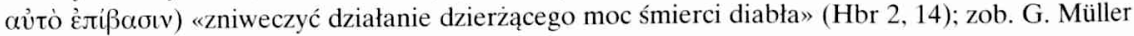
528; Kannengiesser s. 109. 
w ciało. Stosowanie tego rzeczownika w kontekście chrystologicznym jest w ogóle rzadkie: wcześniej użył go w ten sposób tylko Euzebiusz z Cezarei ${ }^{74}$, a później autor Sermo maior $^{75}$. O wiele częściej używano go na oznaczenie zejścia do otchłani, jak to czyniły pisma pseudoatanazjańskie m.in. Contra Apollinarium ${ }^{76}$, a potem Teodoret z Cyru na oznaczenie Bożej obecności w duszy ludzkiej ${ }^{77}$.

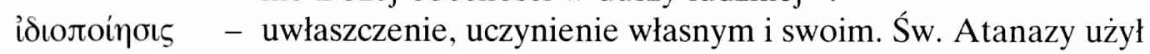
tego rzeczownika, którego istnienia nie odnotowują żadne słowniki greki klasycznej ${ }^{78}$, tylko jeden raz w traktacie $O$ wcieleniu $\mathrm{w}$ znaczeniu przywłaszczenia sobie natury ludzkiej (ciała) przez Słowo ${ }^{79}$. Żaden $z$ autorów wczesnochrześcijańskich, ani wcześniej ani później w tym kontekście go nie używał; jest to więc absolutny atanazjański hapax legome$n^{80}{ }^{80}$, podobnie jak wspominany wyżej używany również w kontekście chrystologicznym czasownik i̊ıлоı́бoua ${ }^{81}$.

\section{WYRAŻENIA}

Obok wyżej wymienionych czasowników i rzeczowników, użytych w kontekście chrystologicznym na oznaczenie tajemnicy wcielenia Słowa Bożego, spotykamy w pismach Atanazego szereg wyrażeń złożonych, starających się w paru słowach wyrazić tę prawdę naszej wiary. Spośród nich wybierzemy tu dla przykładu tylko cztery, określające głównie przebywanie Logosu w ciele, czyli ujmujące wcielenie jako stan.

${ }^{74}$ Por. Demonstratio Evangelica VI 13, PG 22, 433A:

75 Por. Sermo maior 7, PG 26, 1268C: ,Z powodu wejścia, w nie Słowa, ciało nigdy nie

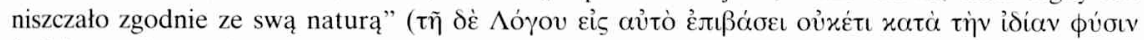

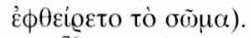

${ }^{76}$ Por. Contra Apollinarium I 7, PG 26, 1105: „w zejściu do hadesu, by zniweczyć śmierć (દ’v

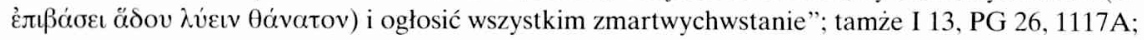
tamże I 17, PG 26, 1125A; tamże II 15, PG 26, 1157A: ,a w jaki także sposób Słowo dokonało

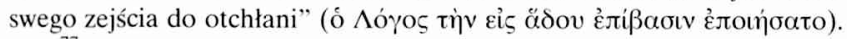

77 Por. In. Ezechielem 28, 16, PG 81, 916; In Psalmum 67, 18, PG 80, 1064; zob. Lampe s. 517.

${ }^{78}$ Nie odnotowuje go ani Greek-English Lexicon H.G. Liddell - R. Scotta, ani Stownik Grecko-Polski I-IV Z. Abramowiczówny.

79 Por. De incarnatione 8, 4, SCh 199, 294, PSP 61, 29: „Z powrotem zwróciło ich [Słowo] ku

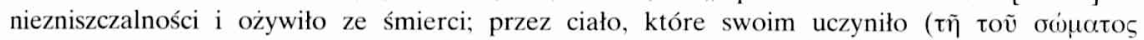

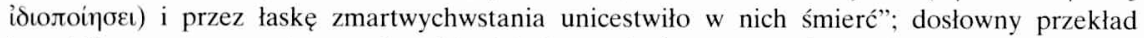
brzmiałby: „przez przywłaszczenie sobie ciała i przez łaskę zmartwychwstania”.

${ }^{80}$ Por. Müller 662; Lampe s. 664; Kannengiesser s. 109.

${ }^{81}$ Por. Ps-Athanasius, Contra Arianos IV 22, PG 26, 500C; Contra Apollinarium I 12, PG 26, 1113A; tamże I 13, PG 26, 1116B; zob. wyżej n. 34-36. 


\section{A oto one:

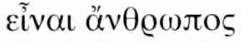 \\ ( jest równocześnie człowiekiem lub w człowieku przez przy- jęcie jego natury. Choć G. Müller nie wyróżnia w swoim słowniku tego wyrażenia, to jednak zaznacza je Ch. Kannen- giesser $^{82}$, który w atanazjańskim traktacie $O$ wcieleniu zau- waża przynajmniej cztery takie narzucające się przykłady ${ }^{83}$.}

عĩval દ̉v

$\sigma \omega ́ \mu \alpha \tau$

- być w ciele, pozostawać w ciele, w znaczeniu, że Słowo Boże pozostaje w ludzkim ciele dla spełnienia jakiejś misji - dla zbawienia człowieka. Wyrażenie to występuje dosyć często w pismach św. Atanazego, my zaś wskażemy tu jedynie 5 jego przykładów wybranych z traktatu $O$ wcieleniu ${ }^{84}$.

$\varepsilon^{\prime} \chi \omega \sigma \tilde{\omega} \mu \alpha \quad$ - posiadać ciało, mieć ciało; w znaczeniu chrystologicznym Słowo Boże ma (nosi) ludzkie ciało, bo inaczej nie mogłoby umrzeć i odkupić człowieka. Wyrażenie to jednak nie występuje w tym kontekście w pismach Atanazego tak często jak poprzednie, ale pojawia się $\mathrm{w}$ nich wyraźnie przynajmniej 7 razy, w tym 2 razy w traktacie $O$ wcieleniu ${ }^{85}$.

${ }^{82}$ Por. Kannengiesser s. 111.

${ }^{83}$ Por. De incarnatione 48, 5, SCh 199, 440, PSP 61, 68: „Jeśli jest człowiekiem (

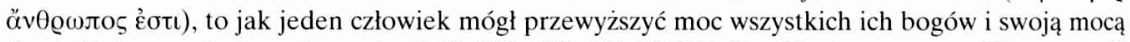
dowieść, że są oni niczym”; tamże 48, 9, SCh 199, 442, PSP 61,68: „Kimże zatem jest Zbawca, jeśli

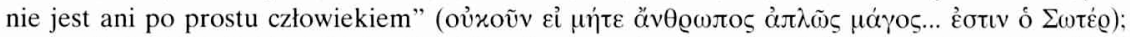
tamże 49, 6, SCh 199, 446, PSP 61, 69: „Albo dlaczego, skoro według nich Chrystus jest człowiekiem ( „by widzących [Słowo] jako człowieka przekonać przez dzieła dokonane, że nie jest ono jedynie

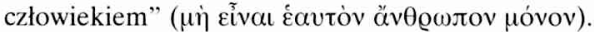

${ }^{84}$ Por. De incarnatione 17, 1, SCh 199, 324, PSP 61, 37: „Nie był bowiem zamknięty w ciele, ani

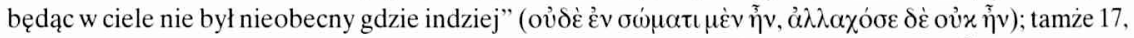

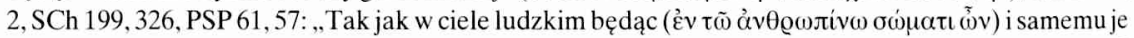
ożywiając, ożywiał również wszystko inne”; tamże 17, 4, SCh 199, 328, PSP 61, 38: „Nie było [Słowo] związane $z$ ciałem, lecz raczej samo nim władało, tak że i w nim było i we wszystkim się znajdowało"

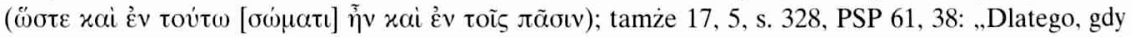

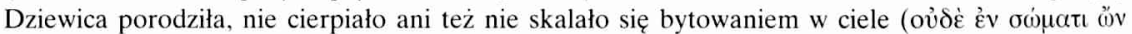

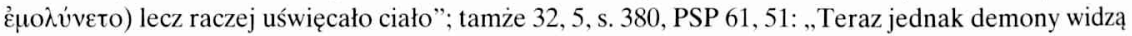
to, w co bezbożni nie wierzą: że jest Bogiem, dlatego uciekają i składają mu hołd mówiąc to, co

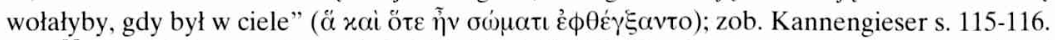

85 Por. De incarnatione 21, 7, SCh 199, 344, PSP 61, 41: „Ponieważ z tego powodu miał ciało

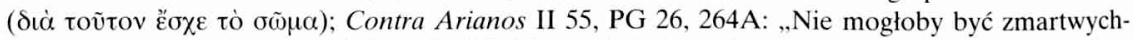
wstania, gdyby go nie poprzedziła śmierć. Jakże zaś śmierć mogłaby je poprzedzić, jeśliby nie miało

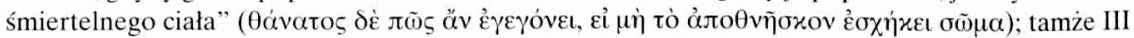

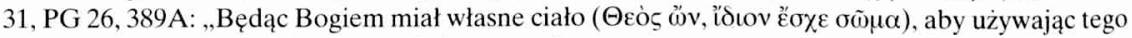
organu stać się człowiekiem ze względu na nas". 
$\phi \varepsilon ́ \varrho \omega ~ \sigma \tilde{\omega} \mu \alpha$ - nosić ciało, w znaczeniu przybrania przez Słowo ludzkiego ciała dla zbawienia człowieka. Wyrażenie to występuje w pismach Atanazego wyraźnie tylko jeden raz $^{86}$ i stanowi swego rodzaju atanazjański hapax legomenon ${ }^{87}$.

Oto kilkanaście wybranych przykładów, które poświadczają, jak bogate, nieustalone i nieprecyzyjne było jeszcze słownictwo, którego Atanazy używał na oznaczenie wcielenia Słowa Bożego. Niektóre z nich przejął z języka potocznego i nadał im treść chrystologiczną, inne przejął z tradycji orygenesowskiej, a jeszcze inne sam stworzył i stosował, ale później nie wszystkie znalazły

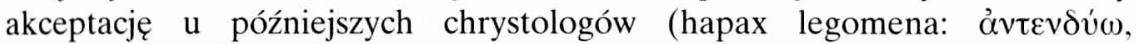

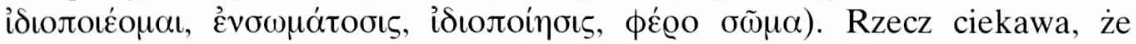

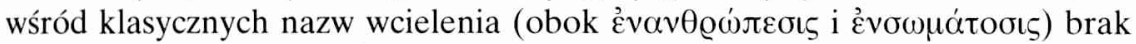

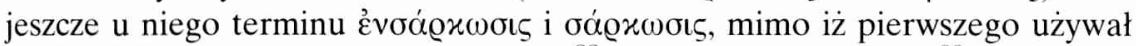
prawie mu współczesny Jan Chryzostom ${ }^{88}$ i Epifaniusz z Salaminy ${ }^{89}$, a drugiego już wcześniej Ireneusz z Lyonu ${ }^{90}$, a współcześnie mu Grzegorz z Nyssy ${ }^{91}$ i pisma pseudoatanazjańskie ${ }^{92}$; być może unikał ich dlatego, iż były to ulubione terminy podejrzewanego o herezję Apolinarego. $\mathrm{Z}$ pochodnych tych terminów używał tylko często (20 razy) przymiotnika évo $\sigma \varrho \varkappa o \varsigma^{93}$. Przez stosowanie wymienionego wyżej i podobnego mu słownictwa Atanazy przyczynił się niewątpliwie w niemałym stopniu do wypracowania i utrwalenia terminologii teologii wcielenia.

${ }^{86}$ Por. De incarnatione 26, 5, SCh 199, 360, PSP 61, 46: „Także dlatego, żeby w wypadku późniejszego wskrzeszenia (ciała) czekającego długo i całkiem zepsutego, uniknąć niedowierzania,

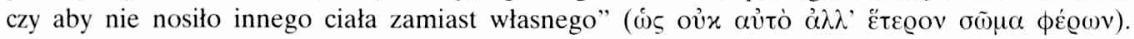
Powyższy przekład jest, jak widać, niedokładny, dosłownie bowiem brzmi: „aby uniknąć niedowierzania, że nosi nie to samo, ale inne ciało".

${ }^{87}$ Por. Kannengiesser s. 114: „L'unique emploi de cette expression chez Athanase”.

${ }^{88}$ Por. In Joannem hom. 75, 1, PG 63, 439.

${ }^{89}$ Por. Haereses 51, 23, PG 41, 932A.

${ }^{90}$ Por. Adversus haereses III 18, 3, i III 19, 1, PG 7, 933A i 939A.

${ }^{91}$ Por. Adversus Apollinarem 38, 2, PG 45, 1209B i 1128A.

${ }^{2}$ Por. Dialogi de Trinitate I 9, PG 28, 1132A.

${ }^{93}$ Por. G. Müller, Lexicon Athanasianum 495. 


\section{DE VERBIS IN DOCTRINA S. ATHANASII DE INCARNATIONE ADHIBITIS}

\section{(Argumentum)}

Hac in dissertatiuncula nonnulla selecta verba ( $\alpha \alpha \lambda \lambda \alpha \mu \beta \alpha \dot{\alpha} v \omega$, $\alpha \dot{v} \tau \varepsilon v \delta \dot{v} \omega$,

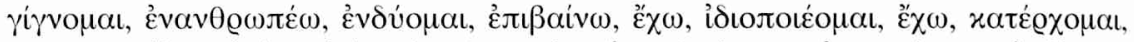

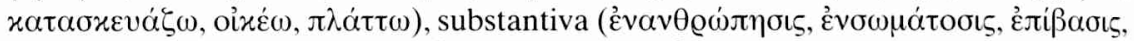

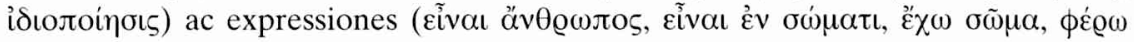
$\sigma \tilde{\omega} \mu \alpha)$ in doctrina S. Athanasii de incarnatione adhibita exponuntur. 